\title{
Conceptual model of sedimentgraph from flood events in a small agricultural watershed
}

\author{
KAZIMIERZ BANASIK ${ }^{1}$, J. KENT MITCHELL ${ }^{2}$ \\ ${ }^{1}$ Department of Water Engineering and Environmental Restoration, Warsaw University of Life \\ Sciences - SGGW \\ ${ }^{2}$ Department of Agricultural and Biological Engineering, University of Illinois at Urbana-Champaign
}

\begin{abstract}
Conceptual model of sedimentgraph from flood events in a small agricultural watershed. A procedure for predicting the sediment graph (i.e. the suspended sediment flux), from a small river catchment by heavy rainfall, has been developed using the concept of an instantaneous unit hydrograph (IUH) and dimensionless sediment concentration distribution (DSCD). A formula for instantaneous unit sedimentgraph (IUSG) is presented, and a procedure for estimating the sediment routing coefficient, which is a key parameter of the IUSG, based on measured data of rainfall-runoff-suspended sediment is applied. Field data from a small, field sized agricultural basin, lacated in center of Illinois has been used for analizing lag times for runoff (LAG) and sediment yield $\left(\mathrm{LAG}_{\mathrm{s}}\right)$. Assumptions about sediment generated during rainfall events are discussed.
\end{abstract}

Key words: sediment graph, IUSG, wash load, watershed lag times.

\section{INTRODUCTION}

Estimates of sedimentgraphs (graphs of suspended sediment load associated with hydrographs caused by rainfall) are essential for sediment yield assessment, providing input data for prediction models of sediment deposition in reservoirs, designing efficient sediment control structures, and water quality predictions. In these cases, and especially in non-point pollution models, in which sediment is a pollutant and transports other pollutants, it is important to estimate sediment transport accurately during individual storms. Offen recorded hysteressis effects in suspended sediment flux (Walling, Webb 1982; Williams 1989; Baca 2008; Tramblay et al. 2008) are taken into account in some of the being developed models (Singh et al. 2008; Sheng 2004; Kalin et al. 2004).

The sedimentgraph model introduced by Williams (1978) was used in previous investigation (Banasik and Woodward 1991; Banasik and Blay 1994). A new definition of the instantaneous unit sedimentgraph (IUSG) was developed (Banasik 1994; Banasik and Walling 1995). The IUSG was incorporated into the sedimentgraph model (SEGMO), based on a lumped parametric approach. The sedimentgraph model, which was developed for predicting watershed response to heavy rainfall, consists of two parts; a hydrologic sub-model and sedimentology sub-model. The hydrologic submodel uses the Soil Conservation Service CN-method to estimate effective rainfall (Woodward et al. 2006), and the 
instantaneous unit hydrograph (IUH) procedure to transform the effective rainfall into a direct runoff hydrograph. The sedimentology submodel uses a form of the modified Universal Soil Loss Equation to estimate the amount of suspended sediment produced during the rainfall-runoff event and the instantaneous unit sedimentgraph (IUSG) procedure to transform the produced sediment into a sedimentgraph.

\section{INSTANTANEOUS UNIT \\ SEDIMENTGRAPH (IUSG) PROCEDURE DESCRIPTION}

The IUSG is defined as the time distribution of sediment generated from an instantaneous burst of rainfall producing one unit of sediment. The IUSG presented here is based on the IUH derived by Nash (1957) i.e.:

$$
u(t)=\frac{1}{k \cdot \Gamma(N)} \cdot(t / k)^{N-1} \cdot \exp (-t / k)
$$

and the first-order kinetic equation written in dimensionless form and termed the dimensionless sediment concentration distribution (DSCD):

$$
c(t)=\exp (-B \cdot t)
$$

where $u(t)$ are the ordinates of the IUH $(1 / \mathrm{h}), \mathrm{N}$ and $\mathrm{k}$ are the Nash model parameters: $N$ is number of reservoirs $(-), \mathrm{k}$ is the retention time of reservoir (hr), $\Gamma(N)$ is the gamma function, $c(t)$ are the ordinates of the DSCD $(-), \mathrm{B}$ is the sediment routing coefficient $(1 / \mathrm{h})$, and $t$ is time (h).

The IUSG is calculated by:

$$
s(t)=\frac{u(t) \cdot c(t)}{\int_{0}^{\infty} u(t) \cdot c(t) d t}
$$

Which, after inserting into it equations 1 and 2 , and solving, produces the following (Banasik 1994):

$$
\begin{aligned}
& s(t)=\frac{B \cdot k+1}{k \cdot \Gamma(N)} \cdot[t(B+1 / k)]^{N-1} \\
& \cdot \exp [-t(B+1 / k)] \text { for } B \geq-1 / k
\end{aligned}
$$

where $s(t)$ are the IUSG ordinates $(1 / \mathrm{h})$. The IUSG has three parameters $N$ and $k$ which are also IUH parameters and a third, the sediment routing coefficient $B$. The IUSG time to peak can be calculated from:

$$
t_{p s}=\frac{(N-1) \cdot k}{1+B \cdot k}
$$

and the maximum ordinate of IUSG can be computed from:

$$
s_{p}=\frac{1+B \cdot k}{k \cdot \Gamma(N)} \cdot \frac{(N-1)^{N-1}}{\exp (N-1)}
$$

where $t_{p s}$ is the time to peak of IUSG (h), and $\mathrm{sp}$ is the maximum ordinate of IUSG $(1 / h)$.

The respective values for IUH are calculated from:

$$
t_{p}=(N-1) \cdot k
$$

and

$$
u_{p}=\frac{1}{k \cdot \Gamma(N)} \cdot \frac{(N-1)^{N-1}}{\exp (N-1)}
$$

where $t_{p}$ is time to peak of the IUH (h), and $u_{p}$ is the maximum ordinate of the $\operatorname{IUH}(1 / \mathrm{h})$, so the ratio of the characteristic values of IUSG and IUH can be computed from:

$$
\frac{t_{p s}}{t_{p}}=\frac{1}{(1+B \cdot k)}
$$


and

$$
\frac{s_{p}}{u_{p}}=1+B \cdot k
$$

It is clear that when $B$ equals zero the characteristic values of IUH and IUSG are the same and right side of equation 4 assumes the form of the Nash IUH (Eq. 1). Also, from Eq. 9, that for $B>0$ time to peak of IUSG is shorter than the time to peak of the IUH, and the peak value of the IUSG is greater than the peak of the IUH (Eq. 10).

\section{EMPIRICAL ESTIMATION OF THE SEDIMENT ROUTING COEFFICIENT}

One of the characteristic values in rainfall-runoff modelling is the retention of the system or lag time, which is defined as the time elapsed between the centroids of effective rainfall and the direct runoff hydrograph. For the IUH derived by Nash, the lag time is estimated using:

$$
L A G=N \cdot k
$$

For the IUSG, the lag time $\left(L A G_{s}\right)$ can be calculated using:

$$
L A G_{s}=\frac{N \cdot k}{1+B \cdot k}
$$

Using equations 11 and 12 , the routing coefficient $B$ can be computed using:

$$
B=\left(L A G / L A G_{s}-1\right) / k
$$

Since the $L A G, L A G_{s}$ and $\mathrm{k}$ can be estimated from rainfall-runoff-suspended sediment data, the routing coefficient $B$, can be estimated using equation 13 .
Using measured data of rainfall-runoff events the lag time can be calculated as:

$$
L A G=M_{1 Q}-M_{1 P}
$$

where $M_{1 Q}$ and $M_{1 P}$ are first statistical moments of the direct runoff hydrograph and the effective rainfall hyetograph (h), respectively. Many attempts have been made to establish the relationship between the watershed lag time and basin characteristics (Snyder 1938; Watt and Chaw 1985; Chang-Xing Jin 1992). Based on measured data, lag time for sedimentgraph, $L A G_{s}$, is defined as time elapsed between centroids of the sediment production graph (similar to effective rainfall hyetograph) and the sedimentgraph, and can be computed from:

$$
L A G_{s}=M_{1 S}-M_{1 E}
$$

where $M_{1 S}$ and $M_{1 E}$ are first statistical moments of the graph of direct suspended sediment rate, and the graph of sediment production (h), respectively. Data from a small agricultural watershed were analysed to investigate the relationship between $L A G_{s}$ and $L A G$, similarly to previous study (Banasik et al. 2005, 2006).

\section{Data description and investigation approach}

Rainfall-runoff-suspended sediment and water quality data from the 2.31 ha (field size) lowland watershed - M3, which is part of the Upper Little Vermilion River catchment, have been collected since 1993 by the Department of Agricultural Engineering, UIUC, within a program of water quality protection in rural areas 
(Mitchell et al. 1997; McIsaac et al. 1997; Walker et al. 1997). The Little Vermilion River is located in East Central Illinois, where the average annual rainfall is approximately $1010 \mathrm{~mm}$ (ISCO, 1998). The M3 watershed has silty loam soils (called Sabina \& Xenia), flat topography (slopes of less than $2 \%$ ) and is totally used for row crop production, primarily corn rotated with soybeans. Rainfall and flow data, as well as time of taking samples by automatic probe sampler, were recorded in one data logger. Up to eight samples were taken for each of the events. The samples were analysed in the water quality laboratory of the Department of Agricultural Engineering, UIUC. Some characteristics of the eight measured events, which have had complete data needed for this analysis, collected in 1993 and 1996, are given in Table 1.

There was no base flow, so the measured runoff hydrographs are equal to the direct runoff hydrographs. Effective rainfall depth for each of the events was estimated as equal to runoff depth. The constant value of losses ( $\Phi$-index) method was selected from four methods which were considered: i.e. SCS, exponential formula, constant runoff coefficient, and constant value of losses (Ignar and Banasik 1994) for determination of effective rainfall distribution during rainfall duration. This method has given the most coherent results, i.e. no negative $L A G$-values, and has the best agreement between regenerated and measured runoff hydrographs.

The distribution of sediment production during rainfall events, i.e. the sediment production graph, needed to estimate lag times for sedimentgraphs $\left(L A G_{s}\right)$ according to equation 15 , was established for four different relationships, representing various assumption about sediment production. Sediment production for each time interval of effective rainfall $\Delta Y_{j}$ was computed from:

TABLE 1. Characteristics of the events

\begin{tabular}{|c|c|c|}
\hline Category & Unit & Value \\
\hline $\begin{array}{c}\text { Rainfall depth } P \\
\text { Avg./event }\end{array}$ & $\mathrm{mm}$ & 25.9 \\
Range & $\mathrm{mm}$ & $10.7-62.7$ \\
\hline $\begin{array}{c}\text { Effective rainfall } H \\
\text { Avg./event }\end{array}$ & 2.36 \\
Range & $\mathrm{mm}$ & $0.25-6.16$ \\
\hline First statistical moments: & $\mathrm{mm}$ & \\
\hline$M_{1 Q}$ for hydrographs & \multicolumn{2}{|c|}{} \\
Avg./event & hour & 1.11 \\
Range & hour & $0.57-1.98$ \\
\hline$M_{1 S}$ for sedimentgraphs & hour & 0.96 \\
Avg./event & hour & $0.40-1.85$ \\
Range & hour & 0.51 \\
\hline$M_{l P}$ for effective rainfall hyetograph & hour & $0.08-1.42$ \\
\hline Avg./event & \multicolumn{2}{|c|}{} \\
Range &
\end{tabular}




$$
\Delta Y_{j}=Y_{j}-Y_{j-1} \text { for } j=1,2, \ldots, n
$$

where $Y_{j}$ is the cumulative sediment production $(M)$ and $\mathrm{n}$ is the number of time intervals of rainfall duration. The relationships for cumulative sediment production used in this study are as follows:

Relationship I

$$
Y_{j}=a_{1} \cdot \sum_{i=1}^{j} \Delta H_{i} \text { for } j=1,2, \ldots, n
$$

Relationship II

$$
\begin{aligned}
& Y_{j}=a_{3} \cdot\left(\sum_{i=1}^{j} \Delta H_{i}^{2}\right)^{b_{1}} \\
& \text { for } j=1,2, \ldots, n
\end{aligned}
$$

Relationship III

$$
Y_{j}=a_{2} \cdot \sum_{i=1}^{j} \Delta H_{i}^{2} \text { for } j=1,2, \ldots, n
$$

Relationship IV

$$
\begin{aligned}
& Y_{j}=a_{4} \cdot\left(\sum_{i=1}^{j} \Delta H_{i} \cdot \Delta P_{i}^{b_{2}}\right)^{b_{3}} \\
& \text { for } j=1,2, \ldots, n
\end{aligned}
$$

where $\Delta P_{i}$ and $\Delta H_{i}$ are incremental rainfall and effective rainfall $(\mathrm{mm})$, and $b_{1}, b_{2}$ and $b_{3}$ are parameters established using a larger set of data from a small watershed in another study (Banasik and Walling 1996). The values of the b-parameters were $0.59,0.56$ and 0.94 , respectively. Finally, $a_{1}, a_{2}, a_{3}$ and $a_{4}$ are fitted parameters, which matched the total sediment production for each event with the measured value. A 10-minute time interval was used in this study. In the first assumption (R-I), sediment production during the rainfall event in each time interval is proportional to effective rainfall in that time interval. In the second assumption (R-II), sediment production is proportional to the squared value of incremental effective rainfall. Parameters $b_{1}$ and $b_{3}$ of the Eqs. 19 and 20 (R-III and R-IV) indicate that for time intervals of the same characteristics; i.e. having the same values of $\Delta H$ and $\Delta H$. - $\Delta P^{b_{2}}$, in Eq. 19 and 20, respectively, sediment production would decrease with time.

\section{Results and Concluding Remarks}

The precision with which the centroids of the direct runoff hydrograph and sedimentgraph can be estimated depends on the accuracy of the measured data, but the precision of estimating centroids of effective rainfall and sediment production, depends also on assumptions about their distributions. In such cases, comparisons of the first moments of direct runoff hydrographs and sedimentgraphs provides an indication of the differences in centroids location and permits some suggestion regarding the differences between $L A G_{S}$ and $L A G$. Mean values and the range of the first moments of direct runoff hydrographs $\left(M_{1 Q}\right)$ and sedimentgraphs $\left(M_{1 S}\right)$ of the measured events are given in Table 1. It can be observed that average as well as extreme values of $M_{1 S}$ were smaller than $M_{1 Q}$. The regression relationship between the first statistical moments of the sedimentgraphs and hydrographs of the eight analysed events was established as:

$$
M_{1 S}=0.978 \cdot M_{1 Q}-0.124
$$


with a coefficient of determination, $\mathrm{r}^{2}=$ $=0.99$, standard error of estimation, $\mathrm{SEE}=0.054$ and standard error of the coefficient (0.978), $\mathrm{SEC}=0.042$. If the constant value in Eq. 21 is constrained to be zero, the relationship becomes:

$$
M_{1 S}=0.882 \cdot M_{1 Q}
$$

with $\mathrm{r}^{2}=0.98, \mathrm{SEE}=0.070$ and $\mathrm{SEC}=$ $=0.021$.

Regression relationships of the forms:

$$
L A G_{S}=a \cdot L A G
$$

and

$$
L A G_{S}=a \cdot L A G+b
$$

were computed for the four different assumptions of sediment production (Tabs 2 and 3, and Fig. 1).

It can be seen from data given in Tables 2 and 3 as well as from Figure 1, that the lag time of sedimentgraphs $L A G_{s}$ is smaller than the lag time for hydrographs $L A G$ (parameter a of Eq. (23) is smaller than 1), for all of the assumptions about sediment production during rainfall events. Relatively high correlation exists for all of the considered relationships, however, a greater coefficient of determination was obtained for Eq. 24.

As lag time for hydrographs, $L A G$, is quite often investigated and some formulae exist for estimating it for small watersheds based on their characteristics, the form of the relationship of Eq. 23, containing only one parameter, seems to be more useful in first stage of investigation of transferring the relationship $L A G_{s}$ vs $L A G$ to other regions, than Eq. 24 which contains two paramters.

The analysis of rainfall-runoff-sediment yield data from the 2.31 ha agricultural watershed in east-central Illinois shows that:

TABLE 2. Characteristics of the relationships of Eq. 23

\begin{tabular}{|l|c|c|c|c|}
\hline \multirow{2}{*}{$\begin{array}{l}\text { Sediment production graph } \\
\text { according to relationship }\end{array}$} & \multicolumn{4}{|c|}{ Characteristics $^{1)}$} \\
\cline { 2 - 5 } & $\mathrm{A}$ & $\mathrm{r}^{2}$ & $\mathrm{SEE}$ & SEC \\
\hline R-I (Eqn 17) & 0.771 & 0.938 & 0.051 & 0.029 \\
\hline R-II (Eqn 18) & 0.700 & 0.829 & 0.094 & 0.053 \\
\hline R-III (Eqn 19) & 0.783 & 0.947 & 0.045 & 0.025 \\
\hline R-IV (Eqn 20) & 0.775 & 0.948 & 0.047 & 0.026 \\
\hline
\end{tabular}

1) $\mathrm{a}$ - parameter of the regression relationship (Eq. (23)); $\mathrm{r}^{2}$ - coefficient of determination; SEE standard error of estimation; SEC, standard error of coefficient a.

TABLE 3. Characteristics of the relationships of Eq. 24

\begin{tabular}{|l|c|c|c|c|c|}
\hline \multirow{2}{*}{$\begin{array}{l}\text { Sediment production graph } \\
\text { according to relationship }\end{array}$} & \multicolumn{5}{|c|}{ Characteristics $^{2)}$} \\
\cline { 2 - 6 } & $\mathrm{a}$ & $\mathrm{b}$ & $\mathrm{r}^{2}$ & $\mathrm{SEE}$ & $\mathrm{SEC}$ \\
\hline R-I (Eqn 17) & 0.877 & -0.162 & 0.954 & 0.048 & 0.079 \\
\hline R-II (Eqn 18) & 0.940 & -0.072 & 0.896 & 0.080 & 0.131 \\
\hline R-III (Eqn 19) & 0.841 & -0.039 & 0.953 & 0.047 & 0.077 \\
\hline R-IV (Eqn 20) & 0.869 & -0.063 & 0.960 & 0.044 & 0.072 \\
\hline
\end{tabular}

${ }^{2)} \mathrm{a}$ and $\mathrm{b}$ - parameters of the regression relationship (Eq. (24)); $\mathrm{r}^{2}$ - coefficient of determination; SEE - standard error of estimation; SEC - standard error of coefficient a. 


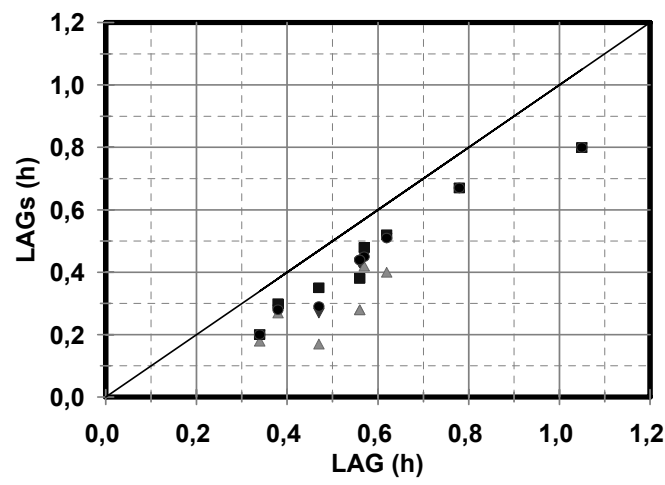

$$
\Delta \mathrm{R}-\mathrm{I} \quad \mathrm{R}-\mathrm{II} \cdot \mathrm{R}-\mathrm{III} \cdot \mathrm{R}-\mathrm{IV}
$$

FIGURE 1. Lag times of the sedimentgraphs, LAGs and lag times of hydrographs for the four assumptions about sediment productions during rainfall evemts for the relationships R-I, R-II, R-III and R-IV

a) a significant linear relationship exists between the lag time of hydrographs, $L A G$, and lag time of the sediment graphs, $L A G s$,

b) parameter $a$ of Eq. 23 may be assumed within the range of $0.70-0.78$, depending on the assumption on sediment production during the rainfall event, for the prediction procedure in similar ungauged watersheds,

c) further analysis using data from this and other watersheds is required to identify the factors controlling the relationship between $L A G_{s}$ and $L A G$, to be able to compute the sediment routing coefficient, B (from Eq. 13).

\section{ACKNOWLEDGMENT}

The study described in this paper has been carried out within the research project 2P06S $050 \quad 30$ and COST 21/2005, founded by Ministry of Science and Higher Education. The financial support provided by this organization is gratefully acknowledged.

\section{REFERENCES}

BACA P. 2008: Hysteressis effect in suspended sediment concentration in the Rybarik basin, Slovakia. Hydrologic Science Journal, 53(1), 224-235.

BANASIK K. 1994: Model sedymentogramu wezbrania opadowego w małej zlewni rolniczej (Sedimentgraph Model of Rainfall Event in a Small Agricultural Watershed) (in Polish with an English summary), Publication of Warsaw Agricultural University - SGGW, p. 120.

BANASIK K. 1995: A conceptual model of the instantaneous unit sedimentgraph. In: Foster I.D.L., Gurnell A.M. and Webb B.W. (eds); Sediment and Water Quality in River Catchments. John Wiley and Sons Ltd., p. 97-106.

BANASIK K., BARSZCZ M., HEJDUK L. 2006: Importance of watershed lag times in IUSG development. In: Sediment Dynamics and the Hydromorphology of Fluvial Systems (Proceedings of a symposium held in Dundee, UK, July 2006). IAHS Publ. 306.

BANASIK K., BLEY D. 1994: An attempt of modelling of suspended sediment concentration after storm event in an Alpine torent. In: Ergenzinger P., and Schmidt K.-H. (eds); Dynamics and Geomprphology of Mountain Rivers. Springer Verlag, Berlin, p. 161-170.

BANASIK K., MADEYSKI M., MITCHEL J.K., MORI K. 2005: An investigation of lag times 
for rainfall-runoff-sediment yield events in small river basin. Hydrologic Science Journal, 50(5), 857-866.

BANASIK K., WALLING D.E. 1996: Predicting sedimentgarphs for a small agricultural catchment. Nordic Hydrology, 27 (4) p. 275-294.

BANASIK K., WOODWARD D.E. 1992: Prediction of sedimentgraph from a small watershedin Poland in changing environment. In: Engman T (ed.); Saving Threatened Resources - in Search of Solution. ASAE, New York, p. 493-498.

CHANG-XING JIN 1993: Determination of the basin lag time in rainfall-runoff investigations. Hydrol. Processes 7, p. 449-457.

IGNAR S., BANASIK K. 1994: An influence of the method for effective rain determination on the parameters of Nash model. Annuals of Warsaw Agricultural University - SGGW, Land Reclamation No 27, p. 77-80.

Illinois State Climatologist Office (ISCO), 1998. Internet address: http://mcc.sws.uiuc.edu/ summary/data/118740.txt

LEE Y.H., SINGH V.P. 2005: Tank model for sediment yield. Water Resources Management. Vol. 19, p. 349-362.

KALIN L., GOVINDARAJU R.S., HANTUSH M.M. 2004: Development and application of a methodology for sediment source indication. I: Modified unit sedimentgraph approch. Journal of Hydrologic Engineering, Vol. 184, p. 184-193.

McISAAC G.F., MITCHELL J.K., WALKER S.E. 1997: Phosphate concentrations in subsurface drainage effluent in east-central Illinois. Paper No 97-2205. ASAE, St. Joseph, MI.

MITCHELL J.K., WALKER S.E., HIRSCHI H.C., McISAAC G.F. 1997: Nitrate losses under various nitrogen management systems. In: Wang S.S.Y., Langendoen E.J., Shields F.D. (eds) Management of Landscapes Disturbed by Channel Incision. The Center for Computational Hydroscience and Engineering. The University of Mississippi, Oxford, p. 197-202.

NASH J.E. 1957: The form of the instantaneous unit hydrograph. Hydrol. Sci. Bull., 3, p. 114-121 .

SHENG Y. 2004: Modeling event-based coupled hydrologic and mass transport in small urban watersheds. A Ph.D. Dissertation at LSU, Agr \& Mech. College. p. 280 (http://etd.lsu.edu/ docs/available/etd-09012004-081308/unrestricted/Sheng_dis.pdf)

SINGH P.K., BHUNYA P.K., MISHRA S.K., CHAUBE U.C. 2008: A sediment graph model based on SCS-CN method. Journal of Hydrology, Vol. 349: p. 244-255.

SNYDER F.F. 1938: Synthetic unitgraph. EOS, 19, p. 447-454.

TRAMBLAY T., St-HILAIRE A., and TAHA, OUARDA T.B.M.J. 2008: Frequency analysis of maximum annual suspended sediment concentrations in North America. Hydrologic Science Journal, 53(1), 236-252.

WALLING D.E., WEBB B.W. 1982: Sediment avalability and the prediction of storm-period sediment yields. In: Recent development in the explanation and prediction of erosion and sediment yield (Proceeding of the Exeter symposium), IAHS Publ. 137, p. 327-337

WALKER S.E., MITCHELL J.K., HIRSCHI M.C., COOKE R.A.C. 1997: Nitrate in agricultural watersheds: a comparison of two tile-drained watersheds in east-central Illinois. Paper No 97-2154. ASAE, St. Joseph, MI.

WATT W.E., CHOW K.C.A. 1985: A general expression for basin lag time. Can. J. Eng. 12, p. 294-300.

WILLIAMS J.P. 1989: Sediment concentration versus water discharge during single hydrologic events in rivers. Journal of Hydrology, Vol. 111: p. 89-106.

WILLIAMS J.R. 1978: A sediment graph model based on the instantaneous unit sediment graph. Water Resour. Res. 14(4), p. 659-664.

WOODWARD D.E., SCHEER C.C., HAWKINS R.H. 2006: Curve number update used for runoff calculation. Annals of Warsaw University of Life Sciences - SGGW, Land Reclamation, No 36, p. 33-42 (http://ann_landreclam.sggw. $\mathrm{pl} /$ landreclam37.pdf).

Streszczenie: Model koncepcyjny sedymentogramu wezbrań powodziowych $w$ matej zlewni znaczania sedymentogramów wezbrań wywołanych ulewnymi deszczami w małej zlewni rolniczej. Procedura zawiera sposób wyznaczania chwilowego sedymentogramu jednostkowego (IUSG), utworzonego z chwilowego hydrogramu jednostkowego (IUH) i bezwymiarowej funkcji koncentracji rumowska unoszonego (DSCD). 
Przedstawiono zależność na określanie nowo wprowadzonego parametru IUSG, na podstawie czasów opóźnienia odpływu wody (LAG) i odpływu rumowiska $\left(\mathrm{LAG}_{\mathrm{s}}\right)$. Dane pomiarowe z małej zlewni rolniczej (o powierzchni 2,31 ha), położonej w centralnej części stanu Illinois wykorzystano do zbadania zależności czasów opóźnienia odpływów wody i rumowiska. Przedstawiono także różne założenia o wytwarzaniu rumowiska w zlewni w trakcie trwania opadu.

MS. received April 2008
Authors' addresses:

Kazimierz Banasik

Katedra Inżynierii Wodnej i Rekultywacji

Środowiska - SGGW

02-787 Warszawa, ul. Nowoursynowska 166

Poland

e-mail: kazimierz_banasik@sggw.pl

\section{J. Kent Mitchell}

Department of Agricultural and Biological

Engineering,

University of Illinois at Urbana-Champaign, 1304 West Pennsylvania Avenue, Urbana, IL 61801, USA 